\title{
RESEARCH NOTE \\ Molecular detection and classification of the phytoplasma that causes purple top in potatoes (Solanum tuberosum) in the State of Mexico
}

\author{
Ana T. Gutiérrez-Ibáñez', Antonio Laguna-Cerda ${ }^{2}$, Reina Rojas-Martínez ${ }^{3}$, \\ Ramiro González-Garza ${ }^{4}$, and Martha L. Salgado-Siclán ${ }^{2}$ \\ ${ }^{1}$ Programa Doctoral en Ciencias Agropecuarias y Recursos Naturales, ${ }^{2}$ Facultad de Ciencias Agrícolas, \\ UAEMex, Campus Universitario Toluca-Ixtlahuaca, Km. 15 entronque al Cerrillo Toluca. Estado de México \\ CP 50200, México. \\ ${ }^{3}$ Colegio de Posgraduados, Carretera México-Texcoco km 36.5 Montecillo. Texcoco CP 56230, México. \\ ${ }^{4}$ BioCiencia S.A. de C.V. Agustín Melgar 2317 Nte, colonia Reforma CP 64550, Monterrey, Nuevo Leon, México.
}

\begin{abstract}
A.T. Gutiérrez-Ibáñez, A. Laguna-Cerda, R. Rojas-Martínez, R. González-Garza, and M.L. Salgado-Siclán. 2012. Molecular detection and classification of the phytoplasma that causes purple top in potatoes (Solanum tuberosum) in the State of Mexico. Cien. Inv. Agr. 39(2): 339-346. The Mexican potato (Solanum tuberosum L.) crop is affected by several diseases, including purple top (PPT). PPT is caused by phytoplasma and is transmitted by insects in the Cicadellidae family. In severe infections, this pathogen can cause yield losses of nearly $100 \%$. The objective of this research was to identify and classify (at a molecular level) the causal agents of PPT. Potato plants were sampled in the state of Mexico (at Tenango del Valle, Zinacantepec, Atlacomulco and Donato Guerra) in the spring and summer of 2006. Approximately $40 \%$ of the plants tested positive for phytoplasma. The presence of plant DNA was determined by amplifying an endogenous gene with the 16s-1/16s-2 primers. To detect phytoplasma, the P1/P7 universal primers were used for PCR, the R16F2n/R16R2 primers were used for nested PCR, and the AluI, HpaII, and KpnI enzymes were used to perform RFLPs. The results indicated that the phytoplasma associated with the PPT disease belongs to the aster yellows (16Sr1) group and the I-B subgroup. The same phytoplasma was found in all three regions of study. When the sequence of the amplified fragment was compared with the registered Gene Bank (NCBI) sequences (using the BLAST package) a homology of $99 \%$ was found with the aster yellows (16Srl) group, "Candidatus Phytoplasma asteris".
\end{abstract}

Key words: Phytoplasma, potato diseases, potato purple top.

\section{Introduction}

Potato is the fifth main crop in Mexico (following wheat, rice, maize and barley). Approximately 67,000 ha are planted through seven regions that

Received June 1, 2010. Accepted March 15, 2011.

Corresponding author: atarini@uaemex.mx include 23 states. Approximately 1.35 million tons of potatoes are produced, which satisfies the domestic consumption demand. This surface covers different regions. The first region in which high-tech agriculture occurs is composed of valleys in which irrigation is used or a stable rain season occurs. This area makes up approximately 17, 000 hectares of the total potato plantations in the 
country, including those in the State of Mexico. The State of Mexico is third in potato production, with a planted area of 4,626.30 ha (SIAP, 2011). This potato crop presents different phytosanitary problems that have affected potato production. These problems are associated with the use of uncertified tuber seed in more than $60 \%$ of the total area of cultivated potatoes. In recent years, diseases caused by phytoplasmas that are transmitted by vector insects in the Cicadellidae family (such as potato purple top (PPT) and potato hair sprout (PHS)) have restricted potato production. These phytoplasmas affect between 70 and 100\% of the national potato production. Overall, the damage varies from 20 to $100 \%$, depending on the degree of infection (Cadena-Hinojosa, 1996). PPT occurs worldwide and is most likely found in some Asian countries. Recently, the occurrence of PPT has decreased in the United States; however, the cause of this decrease remains unknown (Maramorosh, 1998). In Mexico, PPT is one of the main pathogens for potato (Cadena-Hinojosa, 1996; Zavala-Quintana, 2002).

In most potato producing zones, PPT impacts potato quality and yields. Because of the necrosis induced in the interiors of the diseased tubers, PPT hinders or prevents the commercialization of potato crops for fresh consumption or for use in fried flakes. Because potato seeds are sold in Mexico before they sprout, the percentage of seeds that are infected remains unknown. PPT may cause economic losses when infected seeds are planted, which results in a population density that is lower than the target density (Zavala-Quintana, 2002). The observed symptoms vary depending on factors such as variety, the affected organ in the plant, the phenological state of the crop, the infection origin and time of onset, and the prevailing environmental conditions (Martínez-Soriano and López-Flores, 1999).

The plants from infected tubers may manifest the disease 20 days after emerging, depending on the nutrition and humidity conditions. The best-known symptoms include premature plant wilting, vascular necrosis in the stems, short internodes, axillary sprouts that often produce air tubers, curling of recently emerged leaves, and purple leaves (which the disease is named for). The tubers from infected plants are small, low category tubers, and they often present different degrees of internal browning.

The relationship between PPT and the production of fine tuber sprouts is mentioned in previous reports (Nagaich and Giri, 1973; Martínez-Soriano et al., 1997). However, during harvest, the tubers that produce fine sprouts are indistinguishable from normal tubers based on their external and internal appearance. These tubers may only be identified by their elongated and weak sprouts, which occur weeks after harvest. The symptoms of this "ball of twine" disease may be gradual and range from the production of weak sprouts to a total lack of sprouting. Sprouts deficient in chlorophyll are also observed and are identified by white threads, which die and lead to seed necrosis. In some cases, supposedly healthy sprouts allow the emergence of an apparently healthy plant; however, the plant continues to infect and inoculate insects for the dispersion of PPT. These apparently healthy plants produce infected tubers that do not germinate or that germinate deficiently if they are not used as seed (Martínez-Soriano et al., 1997).

To date, the causal agent of PPT has not been identified. Different reports mention that PPT may be associated with the presence of fungi, phytoplasmas (Cadena-Hinojosa, 1996), viruses, or bacteria. In addition, PPT may be caused by the injection of a toxin by Bactericera cockerelli (Sulc.) insects during feeding. However, this toxin has not been isolated, and the metabolic disorder could be due to the presence of metabolites that are produced and introduced by the nymphs of the insect when feeding (Zavala, 2002).

The objective of this work was to identify and classify the phytoplasma that causes PPT in four municipalities that are important for potato pro- 
duction in the State of Mexico (Tenango del Valle, Zinacantepec, Atlacomulco and Donato Guerra).

\section{Materials and methods}

Samples were collected from 100 Alpha variety potato plants that showed PPT symptoms in the spring and summer of 2006. This collection was performed based on previous samplings by the State of Mexico's Comité Estatal de Sanidad Vegetal. Forty of the samples were collected in San Miguel Balderas (Tenango del Valle), 40 were collected in San Juan de las Huertas and San José Contadero (Zinacantepec), 10 were collected in the municipality of Atlacomulco, and 10 were collected in Donato Guerra (Table 1).

Samples from plants with purple-colored leaflets, flat stems (fasciation), air tubers, apical curling of leaves, or shortening of internodes and roots were collected for molecular analysis. The samples were processed in the Centro de Investigación de Estudios Avanzados en Fitomejoramiento (CIEAF) phytopathology laboratory in the Faculty of Agricultural Sciences at the Universidad Autónoma del Estado de México.

Plant DNA was collected with a commercial extraction kit (Plant DNAzol Reagent ${ }^{\circledR}$ (Invi$\left.\operatorname{trogen}^{\mathrm{TM}}\right)$ ). A $0.8 \%$ agarose gel was dyed with ethidium bromide $\left(0.1 \mu \mathrm{g} \mathrm{mL}^{-1}\right)$ to demonstrate the integrity of the extracted DNA. The DNA bands were visualized with a GVM20 Syngene UV light transilluminator. In addition, the quality and concentration of the DNA were measured with an Eppendorf biophotometer. The extracted DNA was diluted in sterilized distilled water to obtain a final concentration of $20 \mathrm{ng} \mu \mathrm{L}^{-1}$. Finally, the diluted DNA was stored at $-20^{\circ} \mathrm{C}$ prior to use (Dellaporta et al., 1983).

\section{Polymerase Chain Reaction (PCR)}

The DNA from each of the samples was subjected to a PCR reaction. The PCR reaction was performed with $16 \mathrm{~s}-1 / 16 \mathrm{~s}-2$ primers that are specific for chloroplasts (endogenous gene). This method amplifies a region of the $16 \mathrm{~S}$ ribosomal gene that is specific for the chloroplast and generates a 315 bp product (Trejo-Saavedra, 2002). This process was used to determine if the vegetal material was free from inhibitor substances. The final PCR reaction concentrations were as follows: $2.5 \mathrm{mM}$ of the PCR $1 \mathrm{X}$ buffer, $2.5 \mathrm{mM}$ of $\mathrm{MgCl}_{2}$ and dNTPs, $10 \mathrm{pmol}$ of each primer, and 1 unit of Taq DNA Polimerase. Each reaction mixture contained $80 \mathrm{ng}$ of DNA and had a final volume of $25 \mu \mathrm{L}$. The samples were amplified in an automatic PTC-100 MJ Research thermal cycler programmed to perform the following steps in sequence: 1) a denaturalization cycle at $94{ }^{\circ} \mathrm{C}$ for $90 \mathrm{~s}$, 2) 35 denaturalization cycles at $94{ }^{\circ} \mathrm{C}$ for $40 \mathrm{~s}, 3$ ) annealing at $55^{\circ} \mathrm{C}$ for $40 \mathrm{~s}, 4$ ) polymerization at $72{ }^{\circ} \mathrm{C}$ for $60 \mathrm{~s}$, and 5) a final extension at $72{ }^{\circ} \mathrm{C}$ for $180 \mathrm{~s}$. The PCR products were analyzed by electrophoresis in $1.5 \%$ agarose gels that were dyed with ethidium bromide $(0.1$ $\mu \mathrm{g} \mathrm{mL}^{-1}$ ) and observed by a GVM20 Syngene UV light transilluminator. The results were documented with the Gene Tools 3.1 software.

Table 1. Geographical locations of the sampling sites that were used to identify the presence of phytoplasmas in potato crops (Solanum tuberosum L.).

\begin{tabular}{lcccc}
\hline \multicolumn{1}{c}{ County } & Location & $\begin{array}{c}\text { Altitude } \\
(\text { masl })\end{array}$ & $\begin{array}{c}\text { Latitude } \\
(\mathrm{N})\end{array}$ & $\begin{array}{c}\text { Longitude } \\
(\mathrm{W})\end{array}$ \\
\hline Tenango del Valle & San Miguel Balderas & 2,857 & $19^{\circ} 06^{\prime} 30.63^{\prime \prime}$ & $99^{\circ} 39^{\prime} 08.72^{\prime \prime}$ \\
Zinacantepec & San Juan de las Huertas & 2,885 & $19^{\circ} 14^{\prime} 36.62^{\prime \prime}$ & $99^{\circ} 45^{\prime} 37.39^{\prime}$ \\
Zinacantepec & San José Contadero & 3,041 & $19^{\circ} 14^{\prime} 12.04 ”$ & $99^{\circ} 48^{\prime} 37.30^{\prime \prime}$ \\
Atlacomulco & Atlacomulco & 2,393 & $19^{\circ} 15^{\prime} 02.46^{\prime \prime}$ & $100^{\circ} 01^{\prime} 05.92^{\prime \prime}$ \\
Donato Guerra & Donato Guerra & 2,212 & $19^{\circ} 18^{\prime} 29.07^{\prime \prime}$ & $100^{\circ} 08^{\prime} 36.84$ “ \\
\hline
\end{tabular}


The obtained fragments were compared with the Ladder $100 \mathrm{pb}$ (Invitrogen ${ }^{\circledR}$ ) molecular weight marker (Trejo-Saavedra, 2002).

Phytoplasma is not usually detected by direct PCR in hosts that have low phytoplasma concentrations. Thus, PCR-nesting was used for phytoplasma detection. The PCR-nesting primers were used to amplify a region of the RNAr 16S (Gundersen and Lee, 1996; Lee et al., 1993) gene. The oligonucleotides or universal primers for phytoplasma (P1/P7) were used in the first PCR reaction, which amplified an $1800 \mathrm{bp}$ fragment (Smart et al., 1996). This reaction was performed at the previously described concentrations with a final volume of $50 \mu \mathrm{L}$. DNA from coconut plants (Cocos nucifera L.) infected with phytoplasmas that cause lethal yellowing was used as a positive control. The DNA from a healthy plant was used as a negative control. The procedure was performed for 35 cycles as follows: 1) denaturation at $94{ }^{\circ} \mathrm{C}$ for $2 \mathrm{~min}, 2$ ) annealing at $54{ }^{\circ} \mathrm{C}$ for $1 \mathrm{~min}$, and 3) polymerization at $72{ }^{\circ} \mathrm{C}$ for 5 min. The direct PCR products were diluted (1:30) with sterile deionized water (free of DNAses and ARNses (GIBCO $\left.{ }^{\circledR}\right)$ ). These dilutions were used to mold DNA for the PCR-nesting. The previously described conditions were used for 30 of the following cycles: 1) denaturalization at $94^{\circ} \mathrm{C}$ for $5 \mathrm{~min}, 2$ ) annealing at $52^{\circ} \mathrm{C}$ for $1 \mathrm{~min}$, and 3) polymerization at $72{ }^{\circ} \mathrm{C}$ for $2 \mathrm{~min}$. The R16F $2 \mathrm{n} /$ R16R2 primers were used to amplify a $1200 \mathrm{bp}$ fragment (Lee et al., 1993).

The final products from both reactions were run in agarose gel at 1 and $1.3 \%$, respectively. The lengths of the obtained fragments were compared with the Ladder $100 \mathrm{pb}$ (Invitrogen ${ }^{\circledR}$ ) molecular weight marker.

\section{Amplified ribosomal product (RFLPS) restriction analysis}

Following the manufacturer's instructions, the PCR products obtained with the R16F2n/R16R2 prim- ers were subjected to digestion with the following endonuclease restrictions (suggested by Lee et al., (1998): AluI, KpnI and HpaII (Invitrogen ${ }^{\circledR}$ ). Five $\mu \mathrm{L}$ of PCR-nested product were added to each reaction with $2 \mu \mathrm{L}$ of buffer and $1 \mu \mathrm{L}$ of each enzyme. The final volume was $20 \mu \mathrm{L}$. This mixture was subjected to $2 \mathrm{~h}$ of incubation at $37^{\circ} \mathrm{C}$. The restriction fragments were separated by electrophoresis in a $3 \%$ agarose gel dyed with ethidium bromide.

The electrophoretic profile of the phytoplasma was compared with the previously reported patterns found in the literature (Lee et al., 1998).

\section{Sequencing, analysis and comparison of sequences}

The PCR products from the R16F2n/R16R2 primers were sent to the Laboratory of Molecular Biochemistry (Unidad de Biología and Prototipos, FES-Iztacala, of Universidad Nacional Autónoma de Mexico) for sequencing. The obtained sequences were compared with the sequences reported in the Bank of Genes (Genbank) of the National Center for Biotechnology Information (NCBI) (Centro Nacional para la Información en Biotecnología). The BLAST-N program was used on site to determine the existing genetic identity of the sequences with respect to those previously reported and deposited in the bank.

\section{Results and discussion}

Symptoms present in the 100 plant samples included flattening of the plant (reduced size and length of internodes), the presence of purple-colored leaflets, stem fasciation, sprouting of air tubers, and apical curling of the leaves (Figure 1).

Obtaining good quality DNA and detecting phytopathogens with molecular techniques are highly important (Leyva-López et al., 2002). In all cases, the collection of total DNA by the Plant DNAzol Reagent ${ }^{\circledR}\left(\right.$ Invitrogen ${ }^{\mathrm{TM}}$ ) method provided good 


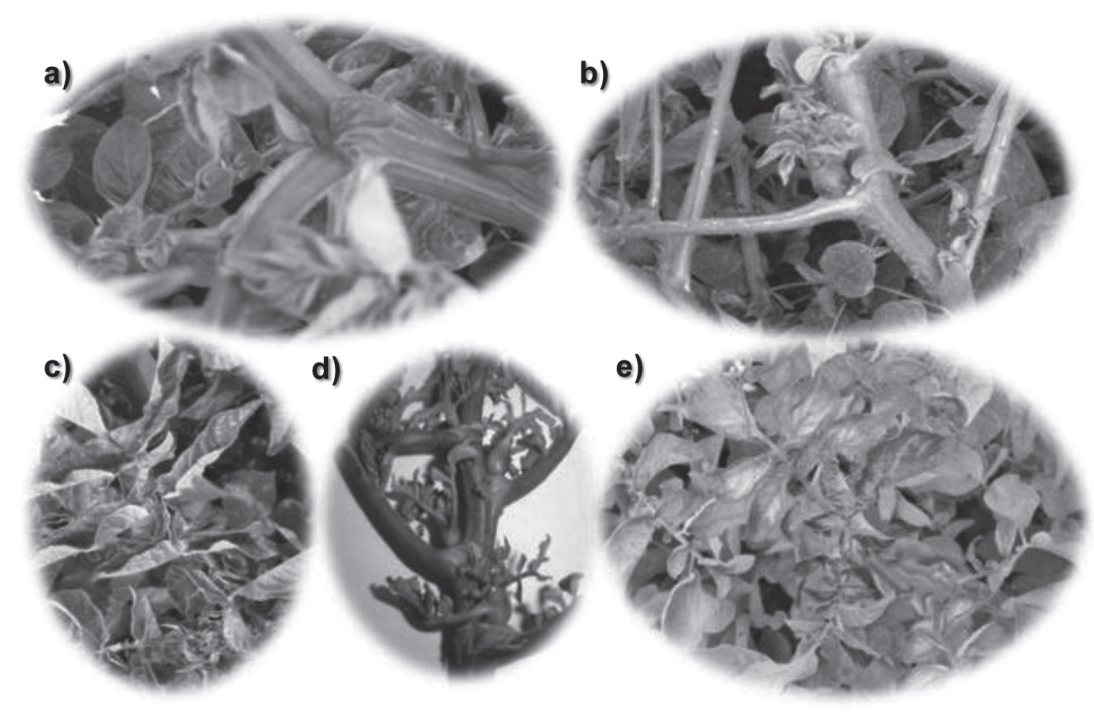

Figure 1. Photos of purple top symptoms: a) smoothed stems, b) air tubers, c) apical rolling of the leaves, d) internodes shortening, and e) purple coloration of the leaflets.

results. In addition, the electrophoresis showed a well defined band for all samples. The concentration and purity of DNA (determined by the biophotometer) were adequate for PCR (1.7-2.0); however, these values indicated contamination by proteins and RNA (indicated by the higher values) (Sambrook et al., 1989).

The absence of PCR inhibitors was verified by amplification of the 16S endogenous gene (TrejoSaavedra, 2002) (Figure 2). For the positive control (C. nucifera) (and for the problem samples), the 315 bp fragment was amplified, and it indicated that the DNA was free from inhibitor PCR substances (such as ethanol, phenols, nucleases and other degrading compounds) (Ausubel et al., 1999). The negative control did not show amplification.

\section{Detection of phytoplasmas}

Because amplification by direct PCR (using the two P1/P7 primers) was not observed, PCR-nesting was conducted for all analyzed samples (except for the positive control). The positive control DNA was extracted from infected coconut plants and characterized by high phytoplasma titers. Furthermore, amplification was not observed in the negative control.

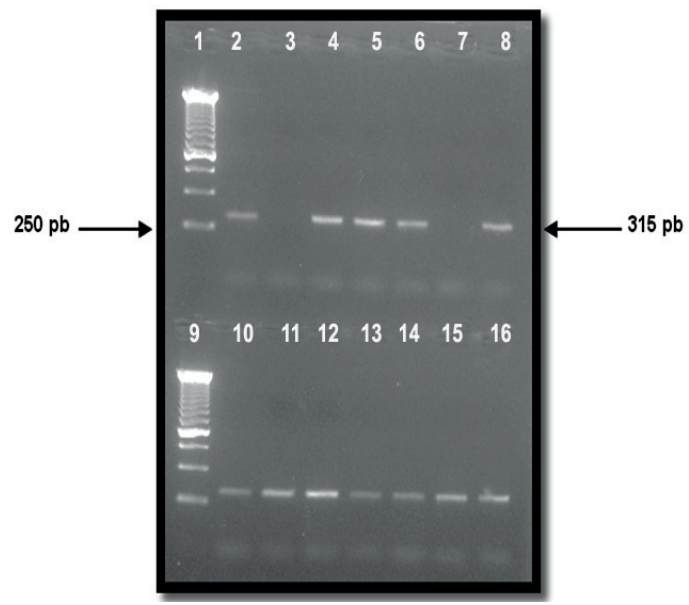

Figure 2. PCR of the $16 \mathrm{~S}$ ribosomal gene in plant DNA. Wells 1 and 9 correspond to the 100 pb DNA Ladders

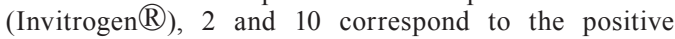
controls, 3 is the negative control (water), and 4-8 and 1116 correspond to the potato plants that showed symptoms. Electrophoresis was conducted in $1.5 \%$ agarose gel dyed with ethidium bromide $\left(1 \mu \mathrm{g} \mu \mathrm{L}^{-1}\right)$ in the TAE $1 \mathrm{X}$ buffer.

A $1200 \mathrm{bp}$ fragment was observed in the nested PCR for the positive control and the problem samples. Therefore, phytoplasma was detected in $40 \%$ of the plants analyzed (Figure 3 ). The negative remains could be associated with other pathogens, such as fungi, viruses or non cultivable bacteria (such as Candidatus Liberibacter solanacearum) (Secor et al., 2009). 


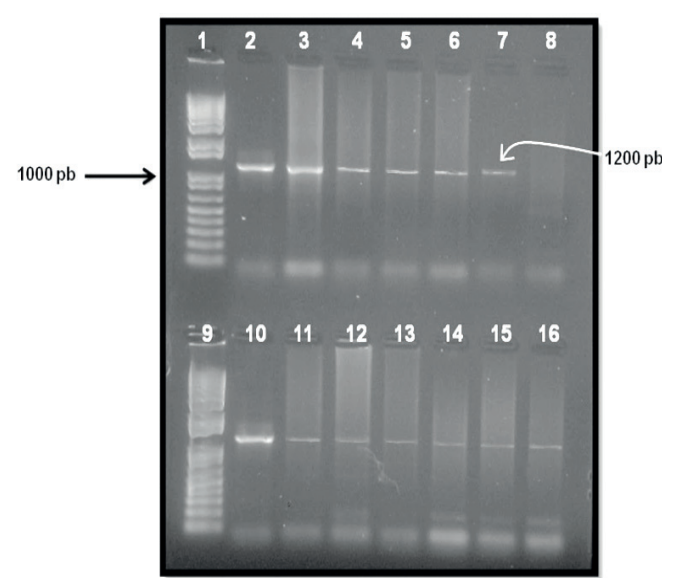

Figure 3. Nested PCR. Wells 1 and 9 correspond to the molecular weight DNA Ladder $1 \mathrm{~Kb}$ (Invitrogen $\mathbb{R}$ ), wells 2 and 10 correspond to the positive controls (ALC), well 8 corresponds to the negative control, and wells 3-7 and 1116 correspond to the potato plant samples. Electrophoresis was conducted in $1.3 \%$ agarose gel dyed with ethidium bromide $\left(1 \mu \mathrm{g} \mu \mathrm{L}^{-1}\right)$ in the TAE $1 \mathrm{X}$ buffer.

These results confirmed the presence of phytoplasma in the four study zones. Overall, $31 \%$ of the positive samples were collected from Tenango del Valle, $43 \%$ were collected from Zinacantepec, 19\% were collected from Atlacomulco and $7 \%$ were collected from the municipality of Donato Guerra (Table 2).

Table 2. The percentages of samples that tested positive for phytoplasmas (by location).

\begin{tabular}{cc}
\hline Location & Positive samples (\%) \\
\hline Tenango del Valle & 31 \\
Zinacantepec & 43 \\
Atlacomulco & 19 \\
Donato Guerra & 7 \\
\hline
\end{tabular}

The phytoplasma was localized indistinctively in the different organs analyzed (except in the root, which is in contrast with the findings of Almeyda et al. (2001). Previous authors determined the sensibility and consistency of the detection of this pathogen in small roots. The phytoplasma was detected in all of the sampled areas, with the highest number of positive samples occurring in the leaflets $(70 \%)$, followed by the air tubers (25\%) and the stems (5\%). The phytoplasma was not detected in the roots.
The 16S DNAr sequence restriction fragment polymorphism length analysis with the R16F2n/ R16R2 primers and with the digestions with AluI, HpaII and KpnI enzymes (Figures 4 and 5) showed persistent patterns in the analyzed samples. The phytoplasma was associated with the aster yellows (16SrI) group and may be located in the I-B subgroup (according to the updated molecular classification of phytoplasmas by Seemüller et al. (1998)).

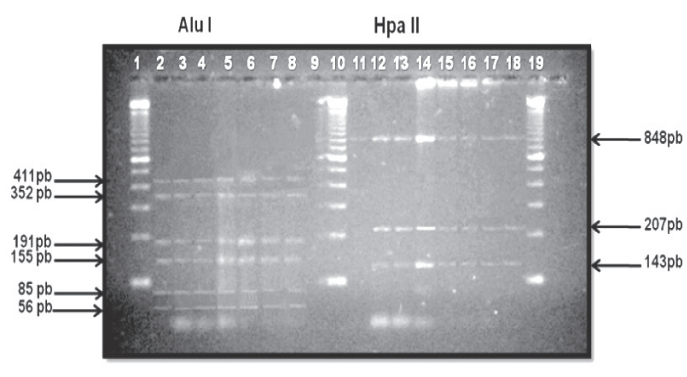

Figure 4. RFLPs using the Alu I and Hpa II restriction endonucleases. The molecular weight DNA Ladders (100 bp) are shown in wells 1,10 and 19 . Wells 2-9 contain the nested PCR products from the potato samples digested with the Alu I enzyme. Wells 11-18 contain the nested PCR products from the potato samples digested with the Hpa II enzyme. Electrophoresis was conducted in $3 \%$ agarose gel dyed with ethidium bromide $(1 \mu \mathrm{g} \mu \mathrm{L}-1)$ in the TAE $1 \mathrm{X}$ buffer.

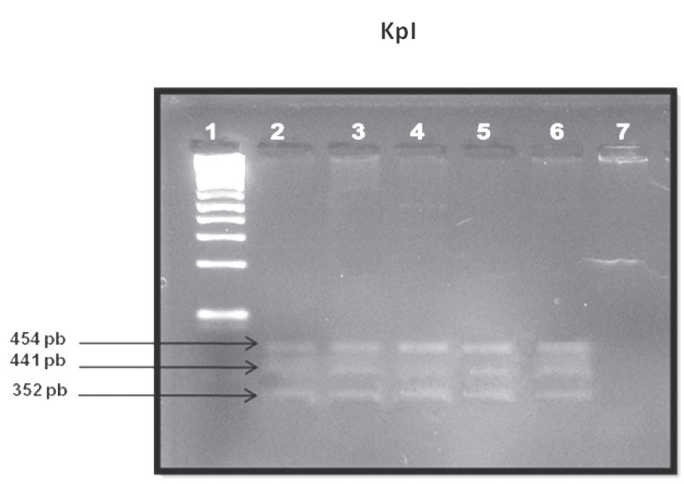

Figure 5. RFLP's using the KpnI restriction endonuclease. Well 1 is the molecular weight DNA Ladder (100 bp). Wells 2-6 contain the nested PCR products from the potato samples that were not digested with the KpnI restriction endonuclease. Electrophoresis was conducted in $3 \%$ agarose gel dyed with ethidium bromide $(1 \mu \mathrm{g} \mu \mathrm{L}-1)$ in the TAE $1 \mathrm{X}$ buffer. 
The sequences obtained from the amplified fragment with the R16F2n/R16R2 primers were compared with the sequences reported previously in the GenBank data bank. The analysis of these sequences showed a $99 \%$ homology with the 16SrI (aster yellows) group (number of access: AF329315) (Lee et al., 1998; Seemüller et al., 1998; Leyva-López et al., 2002).
The similarity among the groups formed by direct PCR and by PCR-nesting and the patterns generated by the restriction enzymes supported the RFLP analysis, which characterizes and differentiates at a group level (Lee et al., 1998). These results correspond with the previous results from Cadena (1993) and Leyva et al. (2002), regarding phytoplasmas in Mexico.

\title{
Resumen
}

\begin{abstract}
A.T. Gutiérrez-Ibáñez, A. Laguna-Cerda, R. Rojas-Martínez, R. González-Garza y M.L. Salgado-Siclán. 2012. Detección y clasificación molecular del fitoplasma causante de la punta morada en papa (Solanum tuberosum), en el Estado de México. Cien. Inv. Agr. 39(2): 339-346. Actualmente el cultivo de la papa (Solanum tuberosum L.) se ve afectado por la enfermedad conocida como punta morada (PMP), la cual es causada por un fitoplasma transmitido por insectos vectores de la familia Cicadellidae, ocasionando pérdidas de hasta un $100 \%$. El objetivo de esta investigación fue la identificación y clasificación molecular del fitoplasma causante de dicha enfermedad. Durante la primavera y verano de 2006 se hizo un muestreo dirigido a plantas con síntomas en los municipios más importantes para la producción de papa en el Estado de México: Tenango del Valle, Zinacantepec, Atlacomulco y Donato Guerra, resultando el $40 \%$ de ellas positivas a fitoplasmas. Se verificó la presencia del ADN vegetal mediante la amplificación del gen endógeno, con los iniciadores 16s-1/16s-2. Para la detección de fitoplasmas se realizó un PCR - directo, con los partidores universales P1/P7, una PCR anidada con los partidores R16F2n/R16R2, y RFLP's del producto de PCR con las enzimas Alu I, Hpa II, KpnI. Se determinó que el fitoplasma, asociado con PMP pertenece al grupo aster yellows (16Sr1) subgrupo I-B, siendo el mismo fitoplasma para las tres regiones en estudio. Al comparar la secuencia del fragmento amplificado con las secuencias registradas en el Gen Bank (NCBI) y con el paquete BLAST, se encontró homología del 99\% con el grupo del amarillamiento del aster (16Srl), "Candidatus Phytoplasma asteris".
\end{abstract}

Palabras clave: Fitoplasma, enfermedades de la papa, punta morada de la papa.

\section{References}

Almeyda-Leon, I.H., M.A., Rocha-Peña, J. Piña-Razo, and J.P. Martínez-Soriano. 2001. The use of polymerase chain reaction and molecular hybridization for detection of phytoplasmas in different plant species in México. Revista Mexicana de Fitopatología. p. 1-9.

Ausubel, F.M., R. Brent, R.E. Kingston, D.D. Moore, J.G. Seidman, J.A. Smith, and K.
Struhl. 1999. Polymerase Chain Reaction. In: Current protocols in molecular biology. Albright L.M., D.M. Coen, and A. Varki (eds.). John Wiley \& Sons, Inc. United States of America. 740 pp.

Cadena H., M.A. 1993. La punta morada en México: Incidencia y búsqueda de resistencia. Agrociencia, serie Protección Vegetal 4: 247-256.

Cadena-Hinojosa, M.A. 1996. La punta morada de la papa en México: II. Efecto cubiertas flotantes, 
cultivares y productos químicos. Revista Mexicana de Fitopatología 14: 20-24.

Dellaporta, S.L., J. Wood, and J.B. Hicks. 1983. A plan DNA minipreparation: Version II. Plant. Mol. Biol. Reporter 1: 19-21.

Gundersen, D.E., and I.M. Lee. 1996. Ultrasensitive detection of phytoplasmas by nested-PCR assays using two universal primer pairs. Phytopathol Mediterranean 35: 144-151.

Lee, I.M., R.W. Hammond, R.E. Davis, and D.E. Gundersen. 1993. Universal amplification and analysis of pathogen 16S rDNA for classification and identification of mycoplasma like organisms. Phytopathology 83: 834-842.

Lee, I.M., D.E. Gundersen-Rindal, R.E. Davis, and I.M. Bartoszyk. 1998. Revised classification scheme of phytoplasmas based on RFLP analyses of 16S rRNA and ribosomal protein gene sequences. International Journal of Systematic Bacteriology 48: 1153-1169.

Leyva-López, N.E., J.C. Ochoa-Sánchez, D.S. LealKlevezas, and J.P. Martínez-Soriano. 2002. Multiple phytoplasmas associated with potato diseases in México. Canadian Journal of Microbiology 48: 1062-1068.

Martínez-Soriano, J.P., and C.I. López-Flores. 1999. La punta morada de la papa. In: Congreso Nacional de Productores de Papa. Guanajuato, México. p. 1-15. Martínez-Soriano, J.P, M. Ríos-Bocanegra, M.E. Zavala-Soto, C. Robles-Urguía, and I.H. AlmeidaLeón. 1997. Detección de organismos tipo micoplasma. In: Congreso Nacional de Productores de Papa, Chihuahua. Chihuahua, México. p. 17-19.
Nagaich, B.B., and K.B. Giri. 1973. Purple top roll disease of potato. American Potato Journal 50: 79-85.

Sambrook, J., E.F. Fritsch, and T. Maniatis. 1989. Molecular cloning: A Laboratory Manual, Second Edition. Cold Spring Harbour Laboratory. New York, USA. p. 16-59.

Secor, G.A., V. Rivera-Vargas, I.M. Lee, G.R.G. Clover, L.W. Liefting, X. Li, and S.H. De Boer. 2009. Association of 'Candidatus Liberibacter solanacearum' with zebra chip disease of potato established by graft and psyllid transmission, electron microscopy, and PCR. Plant Dis. 93:574-583.

Seemüller, E., C. Marcone, U. Lauer, A. Ragozzino, and M. Goschl. 1998. Current status of molecular classification of the phytoplasmas. Journal of Plant Pathology 80: 3-26.

SIAP. 2011. Anuario Estadístico de la Producción Agrícola. SIAP (Servicio de Información y Estadística Agroalimentaria y Pesquera). Available online at: http://www.siap.sagarpa.gob.mx/ar_comdeanuadin.html (Website accessed May 11, 2011).

Smart, C.D., B. Schneider, C.L. Blomquis, L.J. Guerra, N.A. Harrison, U. Ahrens, K.H. Lorenz, E. Semüeller, and B.C. Kirlkpatrick. 1996. Phytoplasmas-specific PCR primers based on secuences of the 16S-23 rRNA spacer region. Applied Environmental Microbiology 62: 2988-2993.

Trejo Saavedra, D.L. 2002. Desarrollo y validación de metodología para la detección de transgenes en organismos genéticamente modificados y sus subproductos. Tesis Centro de Investigación y de Estudios Avanzados del Instituto Politécnico Nacional - Irapuato. Gto. Depto. de Ing. Genética. Guanajuato, México. p. 35-51. 